\title{
Current Issues and Countermeasures of Chinese Labor Exporting in the Context of the Belt and Road
}

\author{
Jingyan Duan \\ International Business School \\ Yunan University of Finance and Economics \\ Kunming, China \\ 20025859@qq.com
}

\begin{abstract}
Under the background of economic globalization and The Belt and Road initiative, it is a great opportunity for China, a developing and populous country to export surplus labors. This opportunity can transform the demographic advantage into the economic advantage, and will be very helpful to alleviate the domestic employment pressure. Nevertheless, China has been practicing labor exporting for over 30 years, but still many issues existed and need to find out. This Paper will analyze the existing problems of China's labor exporting, and propose some feasible countermeasures by taking the development trend of The Belt and Road initiative into consideration.
\end{abstract}

Keywords-The Belt and Road; labor exporting; current issues; countermeasures.

\section{INTRODUCTION}

On the opening ceremony of Belt and Road Forum for International Cooperation in May, 2017, President Xi Jinping reviewed the fruitful achievements from 2014 to 2016. Besides, President Xi also said that he wished The Belt and Road could achieve positive outcomes. In short, "Our aim is to bring visible and tangible benefits to the countries and people along the Belt and Road."

In recent years, some researchers pointed out that China is becoming an aging society, and the demographic dividend would disappear in around 2030. However, China's current employment situation is still grim, which shows large number of university graduates, laid-off workers from enterprises and rural surplus labors also contribute to the increase of employment pressure.The Belt and Road initiative involves sixty-four countries, and more than one hundred cities, including both labor exporting and great amount of labor needs countries. Therefore, relying on this development strategy to export surplus labor would be an effective way to relieve domestic employment pressure, and improve the quality of China's workforce.

\section{The CURRENT ISSUES OF CHINA'S LABORS SERVICES EXPORTING}

After more than 30 years development, China's labor services exporting is still at the exploratory stage. The number of exporting workers and destinations is increasing compared with the initial period, but the exporting ratio in the global labor market is still small. The almost exported labors were non-technical, which meant that the structure of China's labor services exporting was in the single and low-level. There relevant laws and regulations are not comprehensive enough to legalize the governmental management, and there are conflicts between relevant laws and regulations which issued by different departments. This situation leads managerial disorder.

\section{A. Few Exporting Destinations and Labors}

In the early stage of labor exporting, China exported labors abroad by following three main ways, contracting engineering, labor services cooperation, and design consultation.As the development of labor exporting, the types of labor exporting expended from manual works to technical labors, and the industrial types expanded from aid-foreign project construction to manufacturing processing, construction, agriculture, forestry, fishery, husbandry, catering services, and transportation. However, about $75 \%$ non-technical labors were engaged in manufacturing, construction, agriculture, forestry, fishery and husbandry, and up to over $40 \%$ labors worked in manufacturing sector. With regard to regional distribution, the markets of labor exporting set out from the Middle East. Although our country has been keeping exploring new labor markets in Africa and Europe to consolidating traditional markets, most destinations of export labors were still in Asia. After 1995, Chinese labor exporting to Asia has remained at more than $70 \%$, while within Asia, countries like Japan, South Korea, and Singapore have had the most concentrated population of exported labors [1]

The exporting labor proportion of Chinese labor force is low. China has a population of 1.36 billion currently, which is about $19 \%$ of the world's population. China has a total labor force of 930 million, and it is $69.2 \%$ of Chinese population. According to the data published by the Department of Outward Investment and Economic Cooperation of Ministry of Commerce in 2015, China exported 562 thousand various labor employees in 2014. Comparing with the same period last year, this number increased 35 thousand, but it only accounted $0.06 \%$ of China's labor force. The all kinds of 
overseas labor were 1.006 million, which was about $0.1 \%$ of Chinese labor resources [3]. All types of labor forces of China's labor services export have been increasing annually with an upward trend, but only $1.4 \%$ of world's labor demands of about 40 million people every year. Some of the developing countries, such as India, Pakistan, and Egypt, export more than 2 million workers annually. Especially labor export of Philippines was up to over 6 million people, accounting for more than $20 \%$ of the national labor forces [4].

\section{B. Low-level of Labor Services Exporting}

China exports labors as trainees, contracting engineer, electricians, sewers, and construction workers generally. Particularly, these exported labors go to Korea and Russia Far East for agriculture and animal husbandry, go to Symbian for clothing sewing, and go to Singapore for electronics assembly and construction. It is clearly shown that Chinese labors participation and structure in the international division of labor are of low-level and stay at a low end in the international economic system and the International Labor Market.The actualities were extremely inconsistent with the status of China's large population, the export-oriented economic development strategy, as well as the burden to alleviate the increasingly severe domestic employment pressure.

\section{Relevant Laws and Regulations are Imperfect}

The legal system of Chinese labor services exporting is imperfect. For a fairly long period, China has been administering and managing the activities throughout the labor export process in the form of administrative stipulations and notifications.Until May 16, 2012, Regulation on the Administration of Foreign Labor Cooperation (Hereinafter referred to as the Regulation) was adopted, and was officially implemented after August 1, 2012.The promulgation of the Regulation plays a significant role on regulating China's labor services cooperation, which protect the legitimate rights and interests of labor services personnel and promoting the positive development of labor services cooperation. However, comparing with Philippines, the great labor services exporter, there is still a big gap mainly reflected in the following two aspects.

\section{1) The Current legislation is Incomplete}

Chinese current laws, regulations, measures and notifications mainly aim at the processing of formalities of labors goring abroad and management of training agencies. The Regulation contains content regarding to the enterprises and labor personnel engaged in labor services cooperation, contracts related to labor services cooperation, the government's services and management, legal liability, and other aspects, but there has been no provision of any stipulation or content concerned with the responsibility and provided assistance of the authorities or the Labor Services Export Agency to address disputes, difficulties and dangers faced by the labor personnel when in the process of overseas work so far.

\section{2) The Current Legislation is Imperfect}

Chinese regulations of labor exporting issued as Ordinance, Regulation, Measures, and Notifications so far, but without even one special law and the comprehensive legal system. Therefore, the government departments manage the labor exporting by individual issued rules and regulations, which results lack of connection among ordinances, regulations, measures and notifications established by various departments, and even resulting in lawlessness [2].

\section{Unstandarlized of Labor Services Exporting Agency Operations}

Presently, almost Chinese labor exporting agencies operate illegal or advertise as untruly information. Chinese labor services exporting agencies are mostly registered as "XXX Labor Services Cooperation Company" or "XXX Economic and Commercial Labor Services Cooperation Company", which export junior or low-level labors.Some of exporting labors work over seas by those agencies that usually cause two following situations. Firstly, labors are exported illegally with skill trainer after payed high commission fees. These workers usually engage in hard and dirty work conditions, and cannot get any medical insurance. Even their personal safety and security cannot be guaranteed sometimes. Secondly, the agencies use false information to attract labors. For instance, exaggerate or conceal the true situations of the companies of destinations. However, the positions, working conditions, wages and remuneration fall far below the standards promised in the labor contract.

The above problems have existed for years, but nothing changed so far.

\section{MeAsures to ADDRESS PROBlems ABOVE}

The Belt and Road initiative involves 64 countries and more than a hundred cities, including labor exporting countries in Southeast Asia and South Asia, and labor demanded countries, such as the Central Asia, Western Asia and Europe. Therefore, to solve the existing problems, exporting surplus labor by The Belt and Road initiative would be an effective way to create economic benefits as well as social benefits.

\section{A. Increase the Number of exporting labors and Destinations}

To increase the number of labors and destinations, it is essential to be brave enough to Go-out.According to The Belt and Road economic development strategy, the Chinese government should positively seek cooperation opportunities international labor market, and directly contact customers in importing countries to obtain the first-hand information on market demands.In addition, a stable network can be built to expand the sources of information and exporting ways by finding and cooperating with the reputable human resources institutions in importing countries with large labor import.

The Internet is the basis for managing talent pool and collecting market information.Now, the world has entered the big data age, so it is very useful and popular to adopt big data pool to analysis and know the talent information.Designing Chinese and English bilingual website pages for labor services agencies can provide employment information, labor exporters, political regulations, and experience introduction for the job seekers. Besides, it can also provide vacancy 
information for the labor demand markets to establish a network between such a large number of applicants and employers.

\section{B. Expand the Structural Hierarchy of Labor Services Export}

Expanding the hierarchy of labor services export is an effective way to increase the number of exporting workers and destinations.In industries and positions which are scarce in foreign countries but with comparative advantages in China. According to guidance of foreign employers or labor agents, Chinese agencies can recruit and export personnel, such as the accounting, nursing staffs, Chinese medicine practitioners, acupuncturist, cooks, food processing personnel, and electricians, which short in the United Kingdom, Australia, and New Zealand. Besides, Chinese cooks are short in German, and Chinese teachers are short in Southeast Asian countries. According to the needs of foreign labor market, integrating the comparative advantages can not only achieve the targets of increasing both the labor services exporting hierarchy and the number of expatriate workers and destinations, but also enhance China's competitiveness in the market.

\section{Complete Relevant Laws}

In view of the existing legal problems, China should learn from the Philippines. The Philippines based on its national constitution to formulate laws, such as Foreign Project Contracting and Labor Services Cooperation Management Law, and Overseas Employment Promotion Law. China also can base on New Labor Contract Law to supplement relevant legal regulations, which can identify the illegal behaviors in aspects including organizing, exporting and protecting oversea labors,as well as punishment or convictions of these actions in laws or regulations.

China government should adopt the margin system to encourage agencies to comply with relevant laws and regulations.The margin system can increase the entry threshold of agencies, and also can strengthen the punishments on the offending institutions. The national legislation is the only way to show the importance of labor exporting, and it is the valid approach to punish illegal activities of exporting agencies.

In addition, the relevant laws and regulations should protect the rights and interests of the both pre-exporting and overseas workers.The relevant laws and regulations shall specify the responsibility and obligations of agencies when overseas workers encounter life threats, labor disputes, unfair wages and other urgent situations.Besides, agencies should provide assistance in the specified time, otherwise it will be held accountable for their inaction and severely punished.

\section{Strengthen the Organization and Services of Labor Exporting}

The significant issue of China labor export is organizing confusion.In order to eradicate a series of existing problems, China should tackle them from following aspects, such as setting up institutions rationally, enhancing service awareness, and pre-travel training.

Firstly, the government should set up institutions rationally. The Ministry of Commerce and the Ministry of Human

Resources and Social Security should set up the management department together for exporting labor, which should take responsibility to organize, manage and supervise all kinds of affairs. The new set up department need to coordinate the basic functions of sub-departments to avoid the adverse situations, such as conflicts of functions and matters unattended. The effectiveness and efficiency managerial system should be established from the central to local governments completely.

In addition, the Ministry of Foreign Affairs should set up the labor services managerial department in Chinese embassies and consulates around the world, which focus on the labor services exporting affairs, such as the exploration of labor markets, protection of exported labors, and settlement of labor dispute. The above-mentioned managerial departments will promote efficiency and effectiveness of oversea labor management, and it will protect their rights and interests, if the above method carried out effectively.

Finally, the governmental department need to improve the service awareness to provide necessary services and assistance for the exporting process, such as posting recruitment information, providing information proved service, problems solving assistance, and urgent help.

\section{CONCLUSIONS}

To sum up, there are both business opportunities and challenges in the International Labor Markets. Therefore, it is necessary to follow The Belt and Road initiative to solve current labor exporting problems. The above solutions and countermeasures will improve competitive advantages in oversea labor markets. This not only alleviates the domestic employment pressure, but also increases the recognition and economic benefits of China's labor exporting.

\section{ACKNOWLEDGMENT}

This paper is sponsored by Yunnan University of Finance and Economics of basic research project-Youth project No.YC2011B04. Some data and information of this paper is from Pro. Yong Yu. Therefore, thanks for all helps.

\section{REFERENCES}

[1] D. Wang, "Existing Problems and Measures in Chinese Labor Service Export Cooperation," International Economic Cooperation, vol. 8, 2005.

[2] A. Jiang, "Mechanism Analysis on China's Labor Services Export Cooperation," Journal of Shandong University (Philosophy and Social Sciences Version), vol. 6, 2007.

[3] Z. Jin, and Y. Fang, "China's Measures and Legal Improvements on Labor Services Export after Joining WTO," Journal of Qiqihar University (Philosophy and Social Sciences Section). vol. 6, 2004.

[4] Z.H. Sheng, Q. Zhu, and G.M. Wu, "Theory, method and application of DEA,” M. Beijing: Science Press, 1979. 